\author{
国立がんセンター中央病院 \\ 庭川要、蓝賢一、藤元博行、堀江重郎、上井直人、結縁敬治、松岡直樹 \\ 德永卓、垣添忠生
}

【目的】経直腸超音波断層撮影（以下T R U S ）は，泌尿器科領域で前立腺疾患の診断を中心に広く利 用ざ机ている。TRUSの術中への応用を試み、その有用性を検討した。

【方法】仰臥位、全身麻酔下で、下腹部正川切開を加元骨盤内リンバ節郭清を行った。その後に B \& $\mathrm{K}$ 社製Type8551の超音波フロローへを肛門より拌入し，前立腺尖部の切断が終了するまで、手術操作を追い かける形で超音波断層撮影を行った。

【結果】恥骨後式前立腺全摘術中にT R U S を施行し、超音波所見と術中の肉眼所見を比較した。術操 作の鉗子、鈇などの手術器具は，T R U S の画像上容易に同定できた。このため前立腺周囲の三次元棈 造の把握がより容易となった。また、従来のT R U S の解剖学と術中の肉腿による解剖学の対比が可能 であった。尖部㓤井の㮖造や、前立腺と直腸の境界など、術野から直接同定しにくい解剖もTRUSで 明暸に描出され、術中の診断補助として有用であった。

\title{
V-48 経直腸超音波探触子の傾きによる前立腺体積計測值の变動について
}

\author{
東京大分院 ${ }^{1}$ ，東京大 ${ }^{2)}$

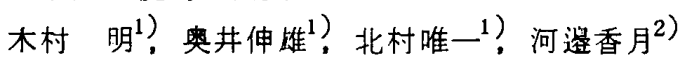

【目的】最大横断像(及び最大継断像) から楕円休で近似して前立腺体積を求める超音波計測法の誤差 は，探触子の傾け方に依存する(Kimura et al. Int J Urol 1995；2:252-256)。したがって，再現性 を高めるためには，走査面を三次元でィメーシしながら検査する必要がある。特に，左右径・前後徉・上 下径と $\pi / 6$ を乗じる方法の場合には 3 軸が淔交するよう注意が必要である。これら注意すべき事項を， 今回は三次元モデルのアニメーションで示した。【対象と方法】正常例 5 例，肥大症10例，㷎 5 例の前 立腺三次元像を. Power Macintosh $8100 / 80 \mathrm{AV}$ と市股のSwivel 3 D という3 D フトで作成した。 スキャナと走查面の模型や，任意の走査面で前立腺を切ったときにできる断面と同じ面積の棈円を左右 径を軸として回転させた回転棈円体の模型，その断面の左右径・前後径に，上下径と $\pi / 6$ を乗じてで きる棈円休の模型も作成し，それらが登場するアニメーションを作成した。【結果】回転棈円体仙過小 詊価する傾向があること，垛蜰子を順け冠状断に近い横断像を取るようにすれば誤差は小さくなること， 3軸を掛け合わせてできる棈円体は 3 粙が直交していないと誤差が大きくなること,などをつニメーシ ヨンで示すことができた。【考祭】前立腺疾患の治療放果判定に用いられる超音波計湘による前立腺体 債は最近，ハンドスキャナにより摄影された横断像と維断像から楕円体で近似して求めることが多い。 経直腸的走查では前立腺輪郭は明瞭に表示できるので, 横断像と縱断像を基に 3 蚰を求め, それらの積 に $\pi / 6$ を乗じて体積を求めるのは，なんら熟練を要さない。しがし 3 軸を計湘する際３軸が直父し ているか留意しながら計測しないと再現性が低くなるが、このことはあまり意識されていないようであ る。この点を強調するためのビデオら゙作成した。 